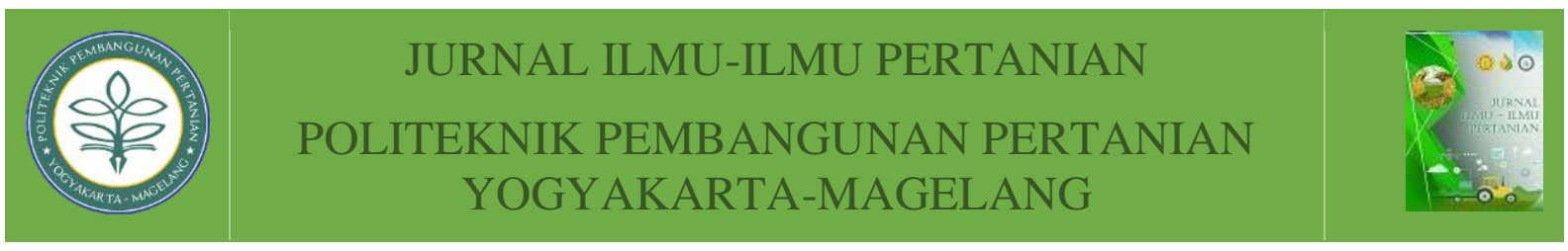

\title{
PENGARUH KONSENTRASI PUPUK ORGANIK CAIR URINE KELINCI DAN FREKUENSI PEMBERIAN TERHADAP PERTUMBUHAN DAN PRODUKSI JAGUNG MANIS (Zea mays L. Saccharata)
}

\author{
Asih Farmia $^{1}$ \\ ${ }^{1}$ Politeknik Pembangunan Pertanian Yogyakarta Magelang, Yogyakarta, 55167
}

Received
Accepted
Published
Copyright Notice
cc) (i)

\author{
March $13^{\text {th }}, 2021$ \\ May $26^{\text {th }}, 2021$ \\ : June $9^{\text {th }}, 2021$
}

ABSTRAK: Jagung manis merupakan salah satu tanaman pangan yang memiliki nilai strategis. Permintaan jagung manis untuk konsumsi terus meningkat, di beberapa pasar lokal permintaan jagung manis bahkan meningkat mencapai 1 hingga 1,5 ton / hari. Untuk itu diperlukan upaya peningkatan produksi Jagung Manis untuk memenuhi permintaan pasar dan konsumen. Tujuan penelitian ini adalah untuk mengetahui pengaruh konsentrasi pupuk cair urine kelinci terhadap pertumbuhan dan produksi jagung manis (Zea mays, L Saccharata). Penelitian dilaksanakan di Politeknik Pembangunan Pertanian Yogyakarta Magelang Kampus Yogyakarta dengan ketinggian $112 \mathrm{~m}$ dpl pada bulan September sampai Desember 2019. Percobaan menggunakan Rancangan Acak Kelompok (RAL) Faktorial yang terdiri dari 2 faktor dan diulang sebanyak 3 kali dengan sbb berikut Faktor: Faktor pertama adalah dosis $P O C$ urine kelinci yang terdiri dari: UO = No Urine (kontrol), U1 = Rabbit Urine $(P O C)(100$ $\mathrm{ml} /$ liter $), U 2=$ Rabbit Urine $(P O C)(200 \mathrm{ml} /$ liter $), P 3=(P O C)$ Urine kelinci $(300 \mathrm{ml} /$ liter $)$, faktor kedua adalah frekuensi pemberian POC dari urine kelinci yaitu K1: 1 kali, K2: 3 kali, K3: 5 kali. Hasil penelitian menunjukkan bahwa frekuensi pemberian POC urine kelinci menunjukkan (1) tidak terdapat perbedaan yang nyata pada tinggi tanaman dan jumlah daun, (2) frekuensi pemberian POC urine kelinci $300 \mathrm{ml} /$ memberikan hasil rata-rata tongkol jagung paling lama panen. Pada hari ke 72 sebesar 24,41 cm (3) frekuensi pemberian POC urine kelinci $200 \mathrm{ml} / \mathrm{l}$ dengan frekuensi pemberian 1 kali pemberian jagung manis terberat yaitu 319,68 gram.

Kata Kunci : konsentrasi, pupuk organik cair (POC) urin kelinci, frekuensi, jagung manis

ABSTRACT: Sweet corn is the food crops that has strategic value. Demand for sweet corn is increasing with the emergence of supermarkets, hotels and restaurants in big cities. The demand for sweet corn for consumption continues to increase, in some local markets the demand for sweet corn has increased even to reach 1 to 1.5 tons / day. Sweet corn production

\footnotetext{
* farmiaasih@gmail.com
} 
from 2012 to 2015 experienced fluctuations (BPS). For this reason, an effort is needed to increase the production of Sweet Corn to meet the demand of the market and consumers. The purpose of this study is to determine the effect of rabbit urine liquid fertilizer (POC) concentration on the growth and production of sweet corn (Zea mays, L Saccharata). The research was conducted at the Agricultural Development Polytechnic of Yogyakarta Magelang, Yogyakarta Campus with a height of $112 \mathrm{~m}$ above sea level from September to December 2019. Experiment using a Factorial Randomized Design (RAL) consisting of 2 factors and repeated 3 times with the following factors: The first factor is the rabbit urine POC doses consisting of: $U O=$ No Urine (control), U1 = Rabbit Urine $(P O C)(100 \mathrm{ml} /$ liter $), U 2=$ Rabbit Urine $(P O C)$ $(200 \mathrm{ml} /$ liter $), P 3=(P O C)$ Rabbit urine $(300 \mathrm{ml} /$ liter $)$, the second factor is the giving frequency of POC from rabbit urine, namely K1: 1 times, K2: 3 times, K3: 5 times. The results showed that the giving frequency of rabbit urine POC showed (1) there was no significant difference in plant height and number of leaves, (2) the frequency giving of rabbit urine POC $300 \mathrm{ml} /$ gave an average yield of corncobs the longest harvested on the $72 \mathrm{nd}$ day is $24.41 \mathrm{~cm}$ (3) the frequency giving of rabbit urine POC $200 \mathrm{ml} / \mathrm{l}$ with a frequency giving of 1 time giving the heaviest sweet corn result is 319.68 grams.

Keywords : concentration. rabbit liquid organic fertilizer, frequency, sweet corn.

\section{PENDAHULUAN}

Jagung merupakan salah satu tanaman pangan yang mempunyai nilai strategis. Jenis jagung bermacam-macam, salah satu diantaranya adalah jagung manis Permintaan jagung manis semakin meningkat dengan munculnya pasar swalayan, hotel dan restaurant di kota-kota besar. Selain itu prospek pasar luar negeri pun masih terbuka. Kebutuhan jagung manis untuk konsumsi terus meningkat di beberapa pasar lokal permintaan terhadap jagung manis meningkat bahkan dapat mencapai $1-1,5$ ton/ hari. Produksi jagung manis dari tahun 2012 - 2015 mengalami fluktuasi (BPS, 2015). (Novizan, 2005)

Data BPS (2015) menunjukkan bahwa terjadi peningkatan impor jagung manis baru sebesar $6,26 \%$ per tahun. Hal ini menandakan bahwa produksi jagung manis nasional belum dapat mencukupi permintaan pasar. Salah satu kendala yang dihadapi yaitu produktivitas jagung manis di dalam negeri yang masih rendah. Produktivitas jagung manis di Indonesia rata-rata 8.31 ton ha (Muhsanati \& Rahayu, 2008) dengan potensi hasil jagung manis mencapai 14-18 ton ha. Melihat hal ini perlu adanya upaya guna meningkatkan produksi jagung manis guna memenuhi permintaan.

Pemupukan merupakan salah satu faktor penting dalam kegiatan budidaya tanaman yaitu dalam pertumbuhan dan perkembangan tanaman. untuk dapat meningkatkan produksi. Sekarang ini pemanfaatan bahan organik sebagai pupuk sudah mulai banyak digunakan seperti pupuk organik. Salah satunya adalah pupuk organik cair (Bio Urine) dari urine hewan seperti kelinci.

Bentuk pupuk organik cair yang berupa cairan dapat mempermudah tanaman dalam menyerap unsur-unsur hara yang terkandung di dalamnya dibandingkan dengan pupuk lainnya yang berbentuk padat. Pupuk cair lebih mudah dimanfaatkan tanaman karena unsur-unsur didalamnya mudah terurai sehingga manfaatnya lebih cepat terlihat.

Kelinci dapat menghasilkan feses atau kotoran dan urin dalam jumlah yang cukup banyak namun tidak banyak digunakan oleh para peternak kelinci. Feses dan urin kelinci lebih baik diolah menjadi pupuk organik daripada terbuang percuma. Hasil penelitian dari Balai Penelitian Tanah tahun 2006 yang dikutip Sembiring, 
Setyobudi, \& Sugito (2017) menuliskan bahwa pupuk organik cair yang berasal dari urin kelinci mempunyai kandungan unsur hara yang cukup tinggi yaitu $\mathrm{N} 4 \%$; $\mathrm{P} 2 \mathrm{O} 5$ 2,8\%; dan $\mathrm{K} 2 \mathrm{O} 1,2 \%$ relatif lebih tinggi daripada kandungan unsur hara pada sapi (

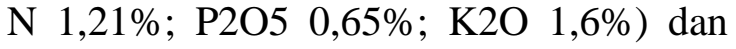
kambing ( N 1,47\%; P2O5 0,05\%; K2O $1,96 \%)$.

Urin kelinci adalah salah satu pupuk organik cair yang memiliki kandungan nitrogen $(\mathrm{N})=2,72 \%$, yang penting bagi tanaman. Unsur $\mathrm{N}$ diperlukan oleh tanaman untuk pembentukan bagian vegetatif tanaman, seperti daun, batang, dan akar serta berperan vital pada saat tanaman melakukan fotosintesis, sebagai pembentuk klorofil (Rosdiana, 2015).Manfaat pupuk organik dari urin kelinci yaitu membantu meningkatkan kesuburan tanah serta meningkatkan produktivitas tanaman (Priyatna dalam Rasyid (2017).

Disamping itu dalam budidaya jagung manis dalam pemupukan juga perlu diperhatikan dosis pemupukan yang tepat sehingga sesuai dengan kebutuhan tanaman. Dosis pemupukan yang tidak tepat pada tanaman dapat menyebabkan tanaman mengalami defisiensi atau kelebihan sehingga pertumbuhan dan hasil tidak maksimal. Oleh karena diperlukan konsentrasi Biourine kelinci yang tepat agar diperoleh hasil yang maksimal. Memang masih sedikit yang melakukan penelitian pemberian konsentrasi POC dari urin kelinci dan frekuensi terhadap pertumbuhan dan produksi jagung manis varietas sweet lady, maka untuk itulah dilakukan penelitian ini .Tujuan penelitian ini adalah untuk mengetahui pengaruh pemberian POC urin kelinci dan frekuensi pemberian terhadap pertumbuhan dan produksi jagung manis varietas sweet boy.

\section{METODE}

Penelitian dilaksanakan di Kebun Praktek Politeknik Pembangunan Pertanian (Polbangtan) Yogyakarta Magelang Kampus Yogyakarta dengan ketinggian tempat $112 \mathrm{~m}$ dpl pada bulan September sampai dengan bulan Desember 2019. Adapun bahan dan alat yang digunakan adalah pupuk organik cair (POC) urin Kelinci yang telah difermentasi , benih jagung manis, pupuk kompos, pupuk urea, pupuk NPK, pestisida dan alat yang digunakan adalah cangkul, alat bajak, tali, tiang pancang, alat tugal, gelas ukur, ember, gembor.Percobaan menggunakan Rancangan Acak Kelompok (RAL) Faktorial yang terdiri dari 2 faktor dan diulang sebanyak 3 kali dengan faktor sebagai berikut : faktor pertama ialah dosis POC urin kelinci terdiri dari :U0 = Tanpa Urin (control), U1 = POC Urin Kelinci $(100 \mathrm{ml} /$ liter $)$, U2 = POC Urin Kelinci (200 ml/liter) U3 = POC Urin Kelinci (300 $\mathrm{ml} /$ liter) dan faktor kedua adalah frekuensi pemberian POC dari urine kelinci yaitu: K1: 1 kali, K2: 3 kali, K3: 5 kali dan setiap perlakuan diulang sebanyak tiga kali, serta setiap ulangan terdapat empat sampel tanaman, Pengamatan meliputi pertumbuhan dan pengamatan panen. Pengamatan pertumbuhan yaitu tinggi dan jumlah daun.

Pengamatan panen yaitu panjang tongkol dan berat tongkol. Perlakuan POC urine kelinci diberikan dengan cara disiramkan ke daerah perakaran dua minggu sekali sedangkan perlakuan kontrol hanya disiram dengan air. Data hasil pengamatan dalam percobaan dianalisis dengan uji $\mathrm{F}$ dengan taraf 5\% dan apabila analisis menunjukan beda nyata maka dilanjutkan dengan uji (BNT) pada taraf $=0,5 \%$. 
HASIL DAN PEMBAHASAN

Tabel 1. Jumlah Daun

\begin{tabular}{ccccc}
\hline PERLAKUAN & K1 & K2 & K3 & $\begin{array}{c}\text { RERATA } \\
\text { BNT 5\% }(3,34)\end{array}$ \\
\hline U1 & $7.30 \mathrm{a}$ & $7.66 \mathrm{~s}$ & $6.42^{\mathrm{a}}$ & $7.13^{\mathrm{a}}$ \\
U2 & $6.06 \mathrm{a}$ & $6.86 . \mathrm{a}$ & $8.00^{\mathrm{a}}$ & $6.97^{\mathrm{a}}$ \\
U3 & $7.05 \mathrm{a}$ & $6.70 \mathrm{a}$ & $7.17^{\mathrm{a}}$ & $6.97^{\mathrm{a}}$ \\
Rerata BNT 5\% (3.34) & $6.80 \mathrm{a}$ & $7.07 \mathrm{a}$ & $6.80^{\mathrm{a}}$ & BNT 5\% (5.80) \\
\hline
\end{tabular}

Keterangan:

Angka -angka yang diikuti huruf yang sama pada kolom umur yang sama menunjukkan tidak berbeda nyata berdasarkan BNT $5 \%$.

Hasil analisis pada tabel 1 menunjukan tidak terjadi interaksi nyata antara perlakuan konsentrasi dan frekuensi pemberian pupuk urine kelinci terhadap jumlah daun Dari tabel terlihat bahwa jumlah daun terbanyak pada perlakuan POC urine kelinci konsentrasi $200 \mathrm{ml} / \mathrm{l}$ dengan frekuensi pemberian 5 kali memberikan jumlah daun terbanyak.

Pemupukan dengan menggunakan bahan organik dapat dijadikan sebagai alternatif karena pada bahan organik mampu memperbaiki sifat fisik, kimia dan biologi pada tanah. Pada tinggi tanaman hasil analisa tidak menunjukkan ada beda nyata antar perlakuan, hal ini diduga bahwa pemberian POC urine kelinci dengan konsentrasi 100 ml/l, 200 ml/l dan 300 ml/l sudah memenuhi kebutuhan untuk pertumbuhan vegetatif tanaman seperti tinggi tanaman dengan interval konsentrasi yang tidak terlalu besar dan frekuensi pemberian 1,3 dan 5 dirasa juga intervalnya tidak terlalu jauh yaitu setiap 14 hari sekali.

Hal ini sesuai dengan pendapat Arifin, Isnawan, \& Hariyono (2018) yang mengatakan bahwa pemberian pupuk organik cair dapat merangsang proses fisiologi terhadap proses pertumbuhan tinggi tanaman karena pemberian pupuk organik cair urin kelinci memberikan unsur hara makro dan mikro yang diperlukan oleh tanaman sehingga mampu meningkatkan tinggi tanaman pada selada merah. Kelebihan pupuk organik cair yaitu mudah diserap oleh tanaman karena unsur hara didalamnya sudah terurai dan efek kerjanya cepat serta pengaruhnya dapat terlihat langsung pada tanaman.

Cukupnya ketersediaan dan cepatnya terurai urine dengan konsentrasi $200 \mathrm{ml} / \mathrm{l}$ dengan frekuensi pemberian sebanyak 3 kali diduga memenuhi kebutuhan tanaman jagung dibandingkan konsentrasi dan frekuensi pemberian yang lainnya sehingga menghasilkan tanaman yang paling tinggi tinggi.

Dikuatkan oleh Lakitan (1996) menuliskan bahwa dengan pemberian pupuk organik cair dapat merangsang proses fisiologi terhadap proses pertumbuhan tinggi tanaman. Tinggi tanaman erat kaitannya dengan unsur hara makro yaitu N, P dan K. Sedangkan menurut Sarief dalam Arifin et al., (2018) mengatakan bahwa unsur $\mathrm{N}$ yang diserap tanaman berperan dalam menunjang pertumbuhan vegetatif tanaman seperti akar.

Fosfor juga mempunyai peran terhadap proses pembelahan sel pada suatu titik tumbuh yang berpengaruh pada tinggi tanaman.Lakitan (1996) menyatakan bahwa unsur hara pada kalium juga mempunyai peran sebagai aktivator dari berbagai enzim esensial dalam reaksi reaksi fotosintesis. Fotosintat yang telah dihasilkan kemudian digunakan untuk tanaman pada proses pembelahan sel tanaman, sehingga tanaman akan bertambah tinggi POC urin kelinci dalam penelitian ini mengandung unsur $\mathrm{N} 0,12 \%$, unsur P $0,03 \%$. 
Ini sesuai dengan Hukum Minimum Liebig yaitu bahwa tumbuhnya tanaman tergantung dari faktor-faktor tumbuh yang berada dalam minimum dan besar kecilnya laju pertumbuhan ditentukan oleh peningkatan dan penurunan faktor yang berada dalam jumlah minimum tersebut (Agustina, 1990). Walaupun unsur $\mathrm{N}$ dan $\mathrm{P}$ yang terkandung dalam POC urin kelinci persentasenya kecil tapi masih bisa memberikan pengaruh yang baik dalam pertumbuhan tanaman. Selain itu pemberian urin kelinci pada tanaman yang diaplikasikan dengan cara disiram ke tanah juga sangat membantu tanaman pada proses penyerapan unsur hara (Fitriasari \& Rahmayuni, 2017).

Tabel 2. Tinggi Tanaman

\begin{tabular}{|c|c|c|c|c|c|}
\hline \multicolumn{2}{|c|}{ PERLAKUAN } & K1 & $\mathrm{K} 2$ & K3 & $\begin{array}{c}\text { RERATA } \\
\text { BNT 5\% (53.48) }\end{array}$ \\
\hline & U1 & 61.32 & 71.06 & 66.85 & $66.41^{\mathrm{a}}$ \\
\hline & $\mathrm{U} 2$ & 68,52 & 67.91 & 73.36 & $69.93^{\mathrm{a}}$ \\
\hline & $\mathrm{U} 3$ & 72.90 & 73.09 & 72.56 & $72.85^{\mathrm{a}}$ \\
\hline $\begin{array}{l}\text { Rerata } \\
(53.48)\end{array}$ & BNT $5 \%$ & $67.58 \mathrm{a}$ & $70.69 a$ & $6.80^{\mathrm{a}}$ & BNT 5\% (92.50) \\
\hline
\end{tabular}

Sumber: (Hasil olah data)

Keterangan:

Angka -angka yang diikuti huruf yang sama menunjukkan tidak berbeda nyata berdasarkan BNT5\%; tn

Dari hasil analisis menunjukkan tidak ada beda nyata antara perlakuan kombinasi konsentrasi POC urine kelinci dan frekuensi pemberian pada 14, 28, $42 \mathrm{HST}$. Dari tabel terlihat bahwa tinggi tanaman tertinggi pada pemberian konsentrasi U3 yaitu konsentrasi $300 \mathrm{ml} / \mathrm{l}$ dan pemberian sebanyak 5 kali. Dari hasil analisis menunjukkan tidak ada beda nyata pada jumlah daun tanaman jagung.

Hal ini diduga respon akar terhadap penyerapan unsur hara masih dalam jumlah yang sedikit, karena mikroba yang diberikan ke dalam tanah belum mampu berfungsi secara optimal untuk membantu akar dalam penyerapan unsur hara yang diberikan. Sehingga pemberian pupuk hayati belum mampu memenuhi kebutuhan hara bagi tanaman dalam mendukung pertumbuhan vegetatif termasuk jumlah daun tanaman jagung manis (Khairiyah et al., 2017).

Unsur hara nitrogen $(\mathrm{N})$ yang terdapat dalam urin kelinci sangat berperan dalam pertumbuhan tanaman jagung manis, kadar nitrogen yang diserap akar tanaman sebagian besar akan naik ke daun dan bergabung dengan karbohidrat membentuk protein untuk pembentukan daun. Besarnya unsur hara yang diserap oleh akar akan mempengaruhi jumlah bahan organik dan jumlah mineral yang akan ditranslokasikan, diantaranya untuk pembentukan daun yang akhirnya akan meningkatkan jumlah daun (Wahyudin dalam Rosdiana (2015). Dalam penyerapan unsur hara oleh akar juga dipengaruhi oleh sistem perakaran.

Daerah penyebaran sistem perakaran secara horizontal umumnya 1,5 sampai 2 kali diameter tajuknya (Lakitan, 1996). Dalam penelitian ini semua perlakuan disiramkan di sekitar tajuk tanaman dengan demikian penyerapan unsur hara berjalan baik sehingga hasilnya tidak ada beda nyata antar perlakuan. Pupuk organik cair dilaporkan berpengaruh positif dalam meningkatkan pertumbuhan tanaman jagung, kakao dan sawi.

Aplikasi pupuk organik dalam bentuk cair mudah dilakukan karena unsur hara dalam pupuk organik yang diberikan atau disemprotkan dapat langsung diserap oleh tanaman melalui akar ataupun melalui stomata (Bachtiar et al., 2018). 
Pertumbuhan tanaman berupa panjang tanaman, jumlah daun, dan diameter batang dipengaruhi oleh kandungan bahan organik (karbon organik).

Semakin tinggi bahan organik tersebut, maka pertumbuhan tanaman juga akan semakin meningkat. Sesuai dengan yang dikemukakan oleh Balitnak (2005) diketahui bahwa urine kelinci mengandung unsur hara makro dan mikro yang terdiri dari N P K rata-rata $(\mathrm{N}) 2.72 \%$, (P) $1.1 \%$ dan (K) $0.5 \%$. Urine kelinci dapat bermanfaat memperbaiki struktur tanah, pupuk organik urin kelinci juga bermanfaat untuk pertumbuhan tanaman (Karo, Marpaung, \& Lasmono, 2015).

Hasil penelitian menunjukkan bahwa perlakuan pemberian pupuk organik cair tidak berpengaruh nyata pada semua perlakuan untuk jumlah daun untuk pemberian POC urin kelinci pada 14, 28, 42 HST. Ini sesuai dengan pendapat Hasyiyatun et. al. (2015) yang menuliskan bahwa hal ini juga diduga disebabkan oleh waktu pemberian pupuk organik cair yang kurang tepat.

Pada penelitian ini pemberian pupuk organik cair dilakukan pada 2 dan 4 minggu setelah tanam, sehingga pengaruh yang diberikan sangat lambat dan tidak nampak pada pertumbuhan tanaman mentimun. Pupuk organik cair yang diberikan pada saat tanam bermanfaat sebagai nutrisi pada masa awal pertumbuhan tanaman mentimun yang merupakan tanaman semusim dan memiliki siklus hidup yang relatif pendek, yaitu 45-60 hari.

Dalam penelitian ini, belum terlihat respon akibat pemberian pupuk organik cair, oleh sebab itu pemberian pupuk organik cair pada tanaman mentimun sebaiknya dilakukan pada saat tanam, sehingga unsur hara telah tersedia ketika tanaman memasuki fase pertumbuhan vegetatif awal sebelum memasuki fase generatif, serta frekuensi pemberian yang lebih sering yaitu seminggu sekali.

\section{Panjang Tongkol}

Dari hasil analisis menunjukkan bahwa perlakuan POC urine kelinci tidak ada beda nyata antar perlakuan. Dari tabel 3 dapat terlihat bahwa pemberian konsentrasi 300 $\mathrm{ml} / \mathrm{l}$ dengan frekuensi pemberian 1 kali memberikan hasil rata -rata tongkol jagung yang terpanjang yang dipanen pada hari ke72 seperti terlihat pada tabel 3 .

Tabel.3. Panjang Tongkol (cm)

\begin{tabular}{cc}
\hline PERLAKUAN & PANJANG TONGKOL \\
\hline U1K1 & $21.51^{\mathrm{a}}$ \\
U1K2 & $22.09^{\mathrm{a}}$ \\
U1K3 & $22.84^{\mathrm{a}}$ \\
U2K1 & $23.43^{\mathrm{a}}$ \\
U2K2 & $22^{\mathrm{a}}$ \\
U2K3 & $23.94^{\mathrm{a}}$ \\
U3K1 & $24.41^{\mathrm{a}}$ \\
U3K2 & $23.59^{\mathrm{a}}$ \\
U3K3 & $22.93^{\mathrm{a}}$ \\
BNT & $(5 \%)$ \\
\hline
\end{tabular}

Keterangan:

Angka -angka yang diikuti huruf yang sama menunjukkan tidak berbeda nyata berdasarkan BNT5\%; 


\begin{abstract}
Sedangkan perlakuan POC urine kelinci 100ml/l dengan frekuensi pemberian 1 kali memberikan hasil rata rata tongkol jagung yang terpendek. Dari hasil analisis rata-rata panjang tongkol pada saat panen umur 72 HST menunjukkan bahwa perlakuan konsentrasi POC urin kelinci $200 \mathrm{ml} / \mathrm{l}$ dengan frekuensi pemberian 5 kali memberikan hasil tongkol terpanjang yaitu $23.94 \mathrm{~cm}$. Hal ini disebabkan karena urin kelinci pada konsentrasi tersebut dapat meningkatkan jumlah tongkol dan pengisian biji jagung manis.

Tongkol dan biji jagung manis yang besar dan sempurna merupakan hasil dari kombinasi fotosintesis dan ketersediaan unsur hara serta air yang tercukupi untuk memproduksi putren jagung manis (Fitriasari \& Rahmayuni, 2017). Sawitri dalam Rasyid (2017) menambahkan bahwa kelebihan POC adalah mampu memberikan hara bagi tanaman tanpa merusak unsur hara di dalam tanah dan lebih mudah diserap oleh tanaman.

Pemberian POC urin kelinci dalam penelitian ini walaupun diberikan dengan frekuensi yang paling banyak yaitu 5 kali dengan kombinasi $200 \mathrm{ml} / \mathrm{l}$ dengan frekuensi pemberian 5 kali memberikan hasil tongkol terpanjang, ini sesuai dengan

pendapat Sampurno, Hasanah, \& Barus (2016) yang menyatakan bahwa POC menguntungkan karena tidak merusak tanah dan tanaman walaupun digunakan sesering mungkin. Selain itu, POC memiliki bahan pengikat, sehingga larutan pupuk yang diberikan ke permukaan tanah bisa langsung digunakan oleh tanaman.

Ini yang menyebabkan panjang tongkol antar perlakuan tidak berbeda jauh. Ini sesuai dengan pendapat Wibisono dan Basri dalam Arifin et al. (2018) bahwa tanaman dapat tumbuh dengan sempurna bila apabila unsur hara yang dibutuhkan terpenuhi. Urin kelinci dapat dijadikan sebagai pupuk cair organik yang sangat bermanfaat untuk tanaman. Pupuk cair lebih mudah dimanfaatkan tanaman karena unsur - unsur di dalamnya mudah terurai sehingga manfaatnya lebih cepat terasa (Nugraheni \& Paiman, 2011).

\section{Berat Tongkol}

Dari analisa data menunjukkan ada beda nyata antar perlakuan seperti terlihat pada tabel 4. Untuk berat tongkol menunjukkan bahwa tongkol jagung pada perlakuan POC urine kelinci $200 \mathrm{ml} / \mathrm{l}$ dengan frekuensi pemberian 1 kali memberikan hasil tongkol terberat yaitu 319,68 gram.
\end{abstract}

\begin{tabular}{|c|c|}
\hline \multicolumn{2}{|c|}{ Tabel 4. Berat Tongkol (gram) } \\
\hline PERLAKUAN & BERAT (gr) \\
\hline U1K1 & $216.27^{\mathrm{a}}$ \\
\hline $\mathrm{U} 1 \mathrm{~K} 2$ & $214.52^{\mathrm{a}}$ \\
\hline U1K3 & $216.18^{\mathrm{a}}$ \\
\hline $\mathrm{U} 2 \mathrm{~K} 1$ & $231.18^{\mathrm{ab}}$ \\
\hline $\mathrm{U} 2 \mathrm{~K} 2$ & $319.68^{\mathrm{d}}$ \\
\hline $\mathrm{U} 2 \mathrm{~K} 3$ & $311.35^{\mathrm{cd}}$ \\
\hline U3K1 & $303.017^{\mathrm{c}}$ \\
\hline U3K2 & $295.6^{c}$ \\
\hline U3K3 & $215,40^{\mathrm{a}}$ \\
\hline BNT & $(5 \%)$ \\
\hline
\end{tabular}

Keterangan:

Angka -angka yang diikuti huruf yang sama menunjukkan tidak berbeda nyata berdasarkan BNT5\%; 
Sedangkan perlakuan POC urine kelinci $100 \mathrm{ml} / \mathrm{l}$ dengan frekuensi pemberian 1 kali memberikan hasil rata rata berat tongkol yang terendah yaitu 216,27 gram. Hasil penelitian menunjukkan bahwa tongkol yang paling berat dihasilkan dari perlakuan POC urin kelinci $300 \mathrm{ml} / \mathrm{l}$ dengan frekuensi pemberian sebanyak 1 kali.

Unsur hara $\mathrm{P}$ berperan banyak dalam proses pengisian biji tanaman jagung manis, unsur hara $\mathrm{P}$ akan diserap oleh tanaman secara terus-menerus sampai mendekati masa pematangan biji (Khairiyah et al., 2017). Pupuk cair mengandung unsur hara makro dan mikro, dimana unsur hara mikro berfungsi sebagai activator sistem enzim atau dalam proses pertumbuhan tanaman, seperti fotosintesis dan respirasi. Begitu juga dengan kandungan hara makro yang cukup tersedia bagi kebutuhan tanaman, dapat meningkatkan panjang malai serta mampu meningkatkan hasil tanaman (Sitompul, Simanungkalit, \& Mawarni, 2016).

Pupuk organik cair urine kelinci dapat meningkatkan perkembangbiakan mikroorganisme dalam tanah yang aktif merombak dan melepaskan unsur hara dalam proses pelapukan, sehingga proses dekomposisi akan menggabungkan butir butir tanah lepas yang menyebabkan daya serap air menjadi lebih baik. Pemberian POC urin kelinci mampu menyediakanan hara sehingga meningkatkan kandungan unsur hara dan dapat meningkatkan pertumbuhan dan produksi tanaman (Rasyid, 2017). Memperhatikan Peraturan Menteri Pertanian Nomor : 70/ Permentan/ SR.140/ 10/ 2011 tentang Pupuk Organik, Pupuk hayati dan Bahan Pembenah Tanah menunjukkan bahwa untuk persyaratan teknis minimal pupuk organik cair unsur $\mathrm{N}$ antara $3-6 \%$. Kadar N POC urine kelinci kadarnya $\mathrm{N}$ nya biasanya $4 \%$ (Sembiring et al., 2017).

Dalam penelitian ini POC urin kelinci mengandung unsur $(\mathrm{N}) 0,12 \%$, sehingga dengan pemberian dosis $300 \mathrm{ml} /$ liter memberikan hasil tongkol yang terberat, sedangkan dengan dosis yang sama dan frekuensi yang sering ternyata menghasilkan berat tongkol yang lebih rendah, ini sesuai dengan pendapat Nugraheni \& Paiman (2011) yang mengatakan bahwa diduga pada frekuensi yang lebih tinggi yaitu mengakibatkan keadaan tanah berlebihan air dan kandungan hara yang berlebihan dapat menjadi toksik bagi tanaman tomat.

Frekuensi pemberian urin sebanyak 3 kali menyebabkan kurangnya ketersediaan hara di dalam tanah dan akibatnya proses pertumbuhan tanaman akan terganggu. Ini mengakibatkan tongkol jagung tidak terisi penuh dengan biji jagung ini berpengaruh terhadap berat tongkol jagung manis.

Dalam penelitian ini kandungan POC urine kelinci dari hasil analisa di Laboratorium Penelitian dan Pengujian Terpadu UGM (2017) menunjukkan bahwa kandungan POC urin kelinci yang digunakan mengandung $(\mathrm{N}) \quad 0,12 \%,(\mathrm{P})$ 0,03\%, (K) 0,25\%. Dengan kandungan NPK yang rendah, diduga urine berasal dari kelinci yang berusia muda atau campuran antara kelinci berusia muda dan yang berusia tua. Ini sesuai dengan penelitian Balitnak (2005) yang dikutip dari Imran (2016) yang menuliskan bahwa urin kelinci yang digunakan mengandung unsur hara makro dan mikro $\mathrm{N}, \mathrm{P}$ dan $\mathrm{K}$ masingmasing sebesar (N) 2,72\%, (P) 1,1\%, dan (K) $0,5 \%$.

Jika urin kelinci yang telah diolah menjadi pupuk organik cair di didapat dari ternak yang mencapai umur dewasa 6-8 bulan. Ini karena urin kelinci dewasa telah terbukti paling tinggi dan kaya kandungan unsur N, P dan K. Unsur nitrogen $(\mathrm{N})$ yang terkandung dari urin kelinci bagi tanaman untuk pembentukan bagian vegetatif tanaman, seperti daun, batang dan akar serta berperan vital pada saat tanaman melakukan fotosintesis dengan membentuk klorofil (Balitnak, 2005). 


\section{SIMPULAN DAN SARAN}

Dari penelitian yang telah dilaksanakan dapat disimpulkan bahwa:

1) Pemberian kombinasi konsentrasi POC urine kelinci dan frekuensi pemberian tidak ada beda nyata antar perlakuan pada tinggi tanaman

2) Pemberian kombinasi konsentrasi POC urine kelinci dan frekuensi pemberian tidak ada beda nyata antar perlakuan pada jumlah daun ,.

3) Pemberian POC urin kelinci memberikan hasil tidak ada beda nyata pada panjang tongkol dimana pemberian konsentrasi $300 \mathrm{ml} /$ dengan frekuensi pemberian 1 kali memberikan hasil rata -rata tongkol jagung yang terpanjang yang dipanen pada hari ke-72 yaitu 24,41 $\mathrm{cm}$

4) Pemberian POC urin kelinci memberikan hasil beda nyata pada berat tongkol dengan pemberian konsentrasi $200 \mathrm{ml} / \mathrm{l}$ dengan frekuensi pemberian 1 kali memberikan hasil tongkol terberat yaitu yaitu 319,68 gr.

\section{PUSTAKA ACUAN}

Agustina, L. (1990). Nutrisi Tanaman. Jakarta: Penerbit Rineka Cipta.

Arifin, M., Isnawan, B. H., \& Hariyono. (2018). Kajian Pemberian Konsentrasi POC Urin Kelinci dan Dosis Pupuk Urea terhadap Pertumbuhan dan Hasil Tanaman Selada Merah (Red Lettuce). UMY Repository, 1-19.

Bachtiar, T., Nurrobi Fahmi, Citraresmini, A., Flatian, A. N., Slamet, S., \& Tarmizi. (2018). Peningkatan Produksi Kedelai Hitam Varietas Mutiara 2 Melalui Pemberian Pupuk Organik Cair. Prosiding Seminar Nasional APISORA 2018, 41-48.

Balitnak. (2005). Peranan Unsur Hara N,P,K dalam Proses Metabolisme Tanaman Padi.

BPS. (2015). Produksi Jagung menurut
Provinsi (ton), 1993-2015. Retrieved June 10, 2020, from BPS website: https://www.bps.go.id/dynamictable/ 2015/09/09/868/produksi-jagungmenurut-provinsi-ton-1993-2015.html Fitriasari, C., \& Rahmayuni, E. (2017). Efektivitas Pemberian Urin Kelinci untuk Mengurangi Dosis Pupuk Anorganik pada Budidaya Putren Jagung Manis. Jurnal Agrosains Dan Teknologi, 2(2), 141-156.

Handayani, T., Sholihah, A., \& Asmaniyah, S. (2020). Pengaruh Aplikasi Pupuk Kandang, NPK dan Urine Kelinci Terhadap Pertumbuhan dan Produksi Dua Macam Varietas Tanaman Mentimun (Cucumis sativus .L) Effect. Jurnal Agronisma, 1(1), 1221.

Hasyiatun, Y., Kurniawati, Karyanto, A., \& Rugayah. (2015). Pengaruh Pemberian Pupuk Organik Cair dan NPK (15:15:15) terhadap Pertumbuhan dan Produksi Tanaman Mentimun (Cucumis sativus L.). Jurnal Agrotek Tropika, 3(1), 30-35.

Imran, A. N. (2016). Pengaruh Pemberian Pupuk Urine Kelinci terhadap Produksi Tanaman Cabai Merah di Kabupaten Maros. Jurnal Agrotan, 2(2), 45-52.

Karo, B. B., Marpaung, A. E., \& Lasmono, A. (2015). Efek Teknik Penanaman dan Pemberian Urin Kelinci terhadap Pertumbuhan dan Produksi Tanaman Kentang Granola (Solanum tuberosum L). Prosiding Seminar Nasional Sains Dan Inovasi Teknologi Pertanian, 285-297.

Khairiyah, Khadijah, S., Iqbal, M., Erwan, S., Norlian, \& Mahdiannoor. (2017). Pertumbuhan dan Hasil Tiga Varietas Jagung Manis (Zea Mays Saccharata Sturt) terhadap Berbagai Dosis Pupuk Organik Hayati pada Lahan Rawa Lebak. Ziraa'ah, 42(3), 230-240.

Lakitan, B. (1996). Fisiologi Pertumbuhan dan Perkembangan Tanaman (1st 
ed.). Jakarta: Raja Grafindo Persada.

Maryamah, U., Sutjahjo, S. H., \& Nindita, A. (2017). Evaluasi Penampilan Sifat Hortikultura dan Potensi Hasil pada Jagung Manis dan Jagung Ketan. Buletin Agrohorti, 5(1), 88-97. https://doi.org/10.29244/agrob.5.1.88 $-97$

Muhsanati, A. S., \& Rahayu, S. (2008). Pengaruh Beberapa Takaran Kompos Tithonia terhadap Pertumbuhan dan Hasil Tanaman Jagung manis (Zea mays saccharata Sturt.). Jerami, 1, 8791.

Novizan. (2005). Petunjuk Pemupukan Efektif (L. A. Marianto, Ed.). Jakarta: AgroMedia Pustaka.

Nugraheni, E. D., \& Paiman. (2011). Pengaruh Konsentrasi dan Frekuensi Pemberian Pupuk Urin Kelinci terhadap Pertumbuhan dan Hasil Tomat (Lycopersicum esculentum Mill). UPY, 3(1), 30-39.

Pertanian, P. M. Peraturan Menteri Pertanian No 70/Permentan/SR.140/10/2011 tentang Pupuk Organik, Pupuk Hayati dan Pembenah Tanah, (2011).

Rasyid, R. (2017). Kualitas Pupuk Cair (Bio Urine) Kelinci yang Diproduksi Menggunakan Jenis Dekomposer dan
Lama Proses Aerasi yang Berbeda. Hasanuddin University Repository, 131.

Rosdiana. (2015). Pertumbuhan Tanaman Pakcoy Setelah Pemberian Pupuk Urin Kelinci. Jurnal Matematika Sains Dan Teknologi, 16(1), 01-09. https://doi.org/10.33830/jmst.v16i1.2 18.2015

Sampurno, M. H., Hasanah, Y., \& Barus, A. (2016). Respons Pertumbuhan dan Produksi Kedelai (glycine max (L.)Merril) terhadap Pemberian Biochar dan Pupuk Organik Cair. Jurnal Agroekoteknologi, 4(3), 21582166.

Sembiring, M. Y., Setyobudi, L., \& Sugito, Y. (2017). Pengaruh Dosis Pupuk Urin Kelinci terhadap Pertumbuhan dan Hasil Beberapa Varietas Tomat. Jurnal Produksi Tanaman, 5(1), 132139.

Sitompul, H. F., Simanungkalit, T., \& Mawarni, L. (2016). Respons Pertumbuhan Bibit Kakao (Theobroma cacao L.) terhadap Pemberian Pupuk Kandang Kelinci dan Pupuk NPK (16:16:16). Jurnal Online Agroteknologi, 2(3), 10641071.

DOI : 